\title{
Information and communication technologies in biology teaching from the perspective of covid-19 in the light of studies already carried out
}

Darlane Barbosa de Farias ${ }^{1}$, Andrezza Fabianni Pedrosa dos Santos Lima ${ }^{2}$, Emilly Tainá Batista da Silva $^{3}$, Emivaldo Batista da Silva ${ }^{4 *}$, Joana Bulhões Alvares da Silva Lima ${ }^{5}$, Maria Talita Bernardo Silva $^{6}$, Wanderson Cleyton da Silva ${ }^{7}$, Victor Daniel Barros da Silva ${ }^{8}$, Guilherme Expedito Rosendo da Silva ${ }^{9}$, Jacicleide Maria de Souza ${ }^{10}$, Vivian Helen de Albuquerque ${ }^{11}$, Arlan Cassio de Aguiar ${ }^{12}$, Rute Maria Siqueira Silva ${ }^{13}$, Camilla Guadallupe de Oliveira Lima ${ }^{14}$, Júlio César da Silva Bruce ${ }^{15}$, Lyzandra Leticya de Lima Costa ${ }^{16}$, Eloizy Victoria da Silva ${ }^{17}$, Valeria Correia Barbosa ${ }^{18}$, Valquiria da Silva Gomes ${ }^{19}$, Emanuella Barros de Souza Oliveira Alvares ${ }^{20}$, Rayana Carla Silva de Morais ${ }^{21}$

\section{1,7,10,12 Department of Biology, University Center of Vitória de Santo Antão (UNIVISA), Pernambuco}

2.6,9 Department of Nutrition, University Center of Vitória de Santo Antão (UNIVISA), Vitória de Santo Antão, Pernambuco, Brazil

3 Department of Biomedicine, Post-Graduation in Laboratory Clinical Microbiology (ASCES- UNITA) Caruaru - PE

4,5,11,15,16 Department of Pharmaceutical Sciences, University Center of Vitória de Santo Antão - (UNIVISA) Vitória de Santo Antão, Brazil. 8 Department of Physical Education, UNIBRA- Recife- PE

13,14 Department of Bachelor of Nursing, University Center of Vitória de Santo Antão (UNIVISA)

17 Department of Biomedicine, University Center of Vitória de Santo Antão (UNIVISA)

18,19 Nursing Department, University Center of Vitória de Santo Antão - PE (UNIVISA)

20.21 Department of Biology, Center for Biological Sciences, Professor of the Degree Course in Biology, University Center of Vitória de Santo Antão (UNIVISA), Vitória de Santo Antão, Brazil

E-mail adresses: darlane.2018180012@univisa.edu.br1 (Darlane Barbosa de Farias), andrezzafpslima@hotmail.com2 (Andrezza Fabianni Pedrosa dos Santos Lima), emilly.taina@hotmail.com3 (Emilly Tainá Batista da Silva), emivaldobatista4@gmail.com4 (Emivaldo Batista da Silva),joanafarmacia2018@gmail.com5 (Joana Bulhões Alvares da Silva Lima),mariatalita965@outlook.com6 (Maria Talita Bernardo Silva), professorwanderson2201@gmail.com7 (Wanderson Cleyton da Silva), victor-daniel.0@hotmail.com8 (Victor Daniel Barros da Silva), guilhermenutri1@gmail.com9 (Guilherme Expedito Rosendo da Silva), jacicleidesouza.07@hotmail.com10 (Jacicleide Maria de Souza), vivianalbuquerque902@gmail.com11 (Vivian Helen de Albuquerque), arlan.aguiar@hotmail.com12 (Arlan Cassio de Aguiar), rutesiqueira06@gmail.com13 (Rute Maria Siqueira Silva), camillaguadallupe@gmail.com14 (Camilla Guadallupe de Oliveira Lima), julio.2017186009@univisa.edu.br15 (Júlio César da Silva Bruce), lyzandra.2017286033@univisa.edu.br16 (Lyzandra Leticya de Lima Costa), eloizyv@gmail.com17 (Eloizy Victoria da Silva), valeriacorreiabarbosa2@gmail.com18 (Valeria Correia Barbosa), kilgomessilva10@gmail.com19 (Valquiria da Silva Gomes) emanuella.barros@hotmail.com20 (Emanuella Barros de Souza Oliveira Alvares), rayanacarla@univisa.edu.br21 (Rayana Carla Silva de Morais)

${ }^{*}$ Corresponding author

\section{To cite this article:}

Farias, D.B.; Lima, A.F.P.S.; Silva, E.T.B.; Silva, E.B.; Lima, J.B.A.S.; Silva, M.T.B.; Silva, W.C.; Silva, V.D.B.; Silva, G.E.R.; Souza. J.M.; Albuquerque, V.H.; Aguiar, A.C.; Silva, R.M.S.; Lima, C.G.O.; Bruce, J.C.S.; Costa L.L.L.; Silva, E.V.; Barbosa, V.C.; Gomes, V.S.; Álvares, E.B.S.O.; Morais, R.C.S. Information and communication technologies in biology teaching from the perspective of covid-19 in the light of studies already carried out. International Journal of Sciences. Vol. 3, No. 1, 2022, pp.84-88. ISSN 2763-5392.

Received: 11 24, 2021; Accepted: 12 26, 2021; Published: 01 15, 2022

\begin{abstract}
Despite the difficult time, the pandemic allowed teachers to work on biology curriculum contents. The aim of this study was to present discussions about the main difficulties faced by teachers and students in relation to remote classes in the teaching of biology in the pandemic scenario. The work is an integrative literature review, carried out through the electronic bases of publications: Google Academic, Scientific Electronic Library Online (SciELO) and the Periodic Portal CAPES. Through the keywords: COVID-19; Biology Teaching; Emergency remote education; Digital technologies. The choice of articles was
\end{abstract}


2 Farias, D.B.; Lima, A.F.P.S.; Silva, E.T.B.; Silva, E.B.; Lima, J.B.A.S.; Silva, M.T.B.; Silva, W.C.; Silva, V.D.B.; Silva, G.E.R.; Souza. J.M.; Albuquerque, V.H.; Aguiar, A.C.; Silva, R.M.S.; Lima, C.G.O.; Bruce, J.C.S.; Costa L.L.L.; Silva, E.V.; Barbosa, V.C.; Gomes, V.S.; Álvares, E.B.S.O.; Morais, R.C.S. Information and communication technologies in biology teaching from the perspective of covid-19 in the light of studies already carried out...

limited to those that met the inclusion criteria, so, after pre-reading, 10 articles were selected and used for discussion. In the end, it was remarkable that the faculty was essential in the period of the pandemic of covid-19, in the instruction of students in the face of a new educational paradigm, also emphasizing a better deepening on the subject researched.

Keywords: COVID-19. Biology Teaching. Emergency remote education. Digital technologies.

\section{Introduction}

In basic education, Digital Information and Communication Technologies (TDICs) and Information and Communication Technologies, proposes to ensure the right to learning students, promoting the participation and innovation of pedagogies through ICT, encouraging them to understand in the most appropriate way possible according to the creativity of the teacher (ALVES et al., 2020).

Despite the period of pandemic caused by coronavirus allowed teachers to work on curriculum contents of biology. Given the relevance of the subject, discussing biology teachers, creativity, meanings, efficiency and emotional aspects during the pandemic, will emphasize that the teacher needs to be increasingly recognized, because even if they are not prepared professionally and psychologically, they are always seeking to reinvent themselves and instruct students (PRETTO, 2020).

In view of the increase and rapid transmission of the same, distance measures were applied in a worldwide scope, where in education, with the reflection of the pandemic of the new coronavirus (COVID-19) caused the interruption of faceto-face classes, being replaced by remote education by the ordinance of MEC No. 343, of March17, 2020, in which teachers and students needed to reinvent themselves and adapt, making them increasingly dependent on an education mediated by digital technologies ((MOREIRA et al., 2020; SILVA, 2020).

In this context, during the pandemic period it was necessary to keep students connected with the school, through remote synchronous and asynchronous activities, where technological resources became the easiest way to reach students. Thus, the need to monitor the available technological resources demonstrated that Emergency Remote Education (ERE) challenged teachers, students and even the educational institution itself, becoming a device-mediated model (BENÍCIO; VAZ; PELICIONI, 2021).

With social isolation, everyone's routine suddenly suffered a great impact, where it was necessary to stay indoors, with this closure, education found itself in a challenge, bringing distance education and technology, as a way to mitigate the effects of the pandemic on education. Although it is not yet possible to report the real impacts caused by coping with COVID-19, the difficulties of how to reorganize the work process, in the search to assert a quality similar to that of faceto-face teaching, is already possible to be perceived (MACHADO, 2020).

When it comes to the changing educational landscape, the COVID-19 pandemic anticipated transformations in education, which could possibly occur a few years ahead. Thus, it stimulated a broader debate on the need to care more and more about teaching methods, as well as the importance of ensuring the permanence of students in schools (MOREIRA et al., 2020).

In view of the above presented, the objective of this research is to present discussions about the main difficulties faced by teachers and students in relation to remote classes in the teaching of biology in this new scenario.

\section{Methodology}

This is an integrative literature review study, where the collection was composed of scientific articles researched in electronic databases of scientific publications, being identified the following: Google academic, Scientific Electronic Library Online (SciELO) and the CAPES Journal Portal.

The inclusion criteria adopted for this research were: articles available free of charge indexed in full, in Portuguese and published between 2020 and 2021. Exclusion criteria were: theses, dissertations, unavailable articles and publications in a language other than Portuguese.

There was the crossing of the terms, where the search in the database was performed using the following key words: Emergency remote teaching; Digital technologies; Biology Teaching; COVID-19. Then, a reading of the articles was performed and those that adapted to the proposed theme were selected for analysis, so the main information collected from the articles was used for the discussions of this article expanding the knowledge about the theme addressed.

\section{Results and Discussion}

After research, 67 publications were found (Table 1).

\begin{tabular}{|c|c|c|c|}
\hline \multirow[t]{2}{*}{ DESCRIPTORS } & \multicolumn{3}{|c|}{ DATABASE } \\
\hline & $\begin{array}{c}\text { Google } \\
\text { Academic }\end{array}$ & SCIELO & CAPES \\
\hline Emergency remote education & 5 & 6 & 4 \\
\hline Digital technologies & 6 & 4 & 8 \\
\hline Biology Teaching & 5 & 8 & 6 \\
\hline COVID-19 & 6 & 5 & 4 \\
\hline TOTAL & 22 & 23 & 22 \\
\hline
\end{tabular}

Source: Prepared by the researcher with data collected.

The choice of articles was limited to those that really 
addressed information and communication technologies in biology teaching and that met the inclusion criteria, thus, after complete reading, 10 articles were selected to write analysis and categorization proposed in this study.

From this evaluation of the publications, the articles described in Table1 were obtained, which were used for discussion.

\begin{tabular}{|c|c|c|c|c|c|}
\hline $\mathbf{N}$ & Origin & Article title & Authors & Year & $\begin{array}{c}\text { Considerations/ } \\
\text { thematic }\end{array}$ \\
\hline 01 & $\begin{array}{c}\text { Latin } \\
\text { American } \\
\text { Journal of } \\
\text { Scientific } \\
\text { Studies. }\end{array}$ & $\begin{array}{c}\text { Information } \\
\text { and } \\
\text { Communicatio } \\
\text { n Technologies } \\
\text { (TICs): an } \\
\text { approach in } \\
\text { the remote } \\
\text { teaching of } \\
\text { Chemistry and } \\
\text { Nanotechnolo } \\
\text { gy in schools } \\
\text { in times of } \\
\text { social } \\
\text { distancing. }\end{array}$ & $\begin{array}{l}\text { SANTOS, } \\
\text { D.S. }\end{array}$ & 2021 & $\begin{array}{c}\text { ICT, although } \\
\text { present in many } \\
\text { schools and even in } \\
\text { many homes, were } \\
\text { not as included } \\
\text { within the } \\
\text { methodologies of } \\
\text { traditional classroom } \\
\text { teaching as the main } \\
\text { didactic resource. } \\
\text { The COVID-19 } \\
\text { pandemic } \\
\text { accelerated the } \\
\text { process of including } \\
\text { ICTs in teaching and } \\
\text { new learning } \\
\text { strategies were } \\
\text { rethought. }\end{array}$ \\
\hline 02 & $\begin{array}{c}\text { Ibero- } \\
\text { American } \\
\text { Journal of } \\
\text { Humanitie } \\
\text { s, Sciences } \\
\text { and } \\
\text { Education } \\
\text { - REASE. }\end{array}$ & $\begin{array}{l}\text { Teaching } \\
\text { biology in } \\
\text { times of } \\
\text { pandemic: } \\
\text { creativity, } \\
\text { efficiency, } \\
\text { emotional } \\
\text { aspects and } \\
\text { meanings. }\end{array}$ & $\begin{array}{c}\text { SOARES, M. } \\
\text { D.; } \\
\text { SANTOS, A. } \\
\text { N.B.; } \\
\text { FARIAS, F. } \\
\text { R.; LIMA, } \\
\text { F.G.C. L. }\end{array}$ & 2021 & $\begin{array}{l}\text { The results showed } \\
\text { that the virtual } \\
\text { environment became } \\
\text { the possible learning } \\
\text { space for the training } \\
\text { process, there was a } \\
\text { difficulty in } \\
\text { separating home and } \\
\text { professional } \\
\text { activities. }\end{array}$ \\
\hline 03 & CONEDU. & $\begin{array}{c}\text { Remote } \\
\text { classes in } \\
\text { pandemic } \\
\text { time: } \\
\text { challenges and } \\
\text { perceptions of } \\
\text { teachers and } \\
\text { students. }\end{array}$ & $\begin{array}{c}\text { MIRANDA, } \\
\text { K. K.C. O.; } \\
\text { LIMA, A. S.; } \\
\text { OLIVEIRA, } \\
\text { V.C.M.; } \\
\text { TELLES, } \\
\text { C.B.S. }\end{array}$ & 2020 & $\begin{array}{c}\text { It is necessary a } \\
\text { greater performance } \\
\text { of the family and the } \\
\text { educational } \\
\text { networks, as well as } \\
\text { investment in } \\
\text { technological } \\
\text { resources, among } \\
\text { others, so that the } \\
\text { consequences of this } \\
\text { type of teaching, } \\
\text { adopted in an } \\
\text { emergency way, } \\
\text { generate fewer } \\
\text { negative } \\
\text { consequences in the } \\
\text { school learning } \\
\text { process. }\end{array}$ \\
\hline
\end{tabular}

\begin{tabular}{|c|c|c|c|c|c|}
\hline 04 & $\begin{array}{c}\text { Teaching } \\
\text { of Science } \\
\text { and } \\
\text { Biology in } \\
\text { Non- } \\
\text { School } \\
\text { Spaces } \\
\text { and } \\
\text { Scientific } \\
\text { Dissemina } \\
\text { tion. }\end{array}$ & $\begin{array}{c}\text { What, how and } \\
\text { why teach in } \\
\text { times of } \\
\text { pandemic? An } \\
\text { analysis of the } \\
\text { teacher's } \\
\text { perception } \\
\text { about the use } \\
\text { of the Social } \\
\text { Network } \\
\text { Instagram in } \\
\text { the Remote } \\
\text { Teaching of a } \\
\text { High School } \\
\text { Class. }\end{array}$ & $\begin{array}{l}\text { FREITAS, } \\
\text { T.C. R.C. }\end{array}$ & 2021 & $\begin{array}{l}\text { This report presents } \\
\text { the proof that the use } \\
\text { of Technologies } \\
\text { stimulated and } \\
\text { involved students in } \\
\text { the virtual world in a } \\
\text { responsible and } \\
\text { scientific way, } \\
\text { increasing the } \\
\text { students' learning as } \\
\text { well as the formation } \\
\text { of learning } \\
\text { communities through } \\
\text { the interaction } \\
\text { between the class } \\
\text { and its followers. }\end{array}$ \\
\hline 05 & $\begin{array}{l}\text { Research, } \\
\text { Society } \\
\text { and } \\
\text { Developm } \\
\text { ent. }\end{array}$ & $\begin{array}{c}\text { Teaching } \\
\text { technologies } \\
\text { used in } \\
\text { education in } \\
\text { the COVID-19 } \\
\text { pandemic: an } \\
\text { integrative } \\
\text { review. }\end{array}$ & $\begin{array}{c}\text { NETO, J. S.; } \\
\text { PINE, } \\
\text { F.V.A.; } \\
\text { MATOS, } \\
\text { H.L.; } \\
\text { LOPES, A. } \\
\text { R. O.; } \\
\text { CERQUEIR } \\
\text { A, G.S.; } \\
\text { SOUZA, E. } \\
\text { P. }\end{array}$ & 2021 & $\begin{array}{l}\text { The data report that } \\
\text { the inclusion of } \\
\text { technologies, } \\
\text { especially digital } \\
\text { technologies } \\
\text { incorporated through } \\
\text { platforms to remote } \\
\text { teaching, enable a } \\
\text { better qualification } \\
\text { in teaching, in } \\
\text { addition to } \\
\text { facilitating the } \\
\text { learning of the } \\
\text { developed contents. }\end{array}$ \\
\hline 06 & $\begin{array}{c}\text { Ifes } \\
\text { Science } \\
\text { Magazine. }\end{array}$ & $\begin{array}{l}\text { Education and } \\
\text { covid-19: the } \\
\text { art of } \\
\text { reinventing the } \\
\text { school } \\
\text { mediating } \\
\text { learning } \\
\text { "primarily" by } \\
\text { the tdic. }\end{array}$ & $\begin{array}{c}\text { CANI, J.B.; } \\
\text { SANDRINI, } \\
\text { E. G.C.; } \\
\text { SOARES, } \\
\text { G.M.; } \\
\text { SCALZER, } \\
\text { K. }\end{array}$ & 2020 & $\begin{array}{l}\text { Constata it is that the } \\
\text { digital environment, } \\
\text { with a strategic } \\
\text { integration of } \\
\text { teaching-learning } \\
\text { process and } \\
\text { technologies, offers } \\
\text { numerous effective } \\
\text { remote mediation } \\
\text { resources for } \\
\text { educational use. }\end{array}$ \\
\hline 07 & $\begin{array}{c}\text { Professor's } \\
\text { look. }\end{array}$ & $\begin{array}{c}\text { Educational } \\
\text { actions in } \\
\text { times of } \\
\text { pandemic: } \\
\text { reflections on } \\
\text { biology in } \\
\text { high school. }\end{array}$ & $\begin{array}{c}\text { LIMA, W. } \\
\text { R.; } \\
\text { PEIXOTO, } \\
\text { J.; } \\
\text { ECHALAR, } \\
\text { A.D.L.F. }\end{array}$ & 2020 & $\begin{array}{l}\text { Actions that aim to } \\
\text { preserve the link of } \\
\text { students with the } \\
\text { school. To this end, it } \\
\text { presents possibilities } \\
\text { for organizing } \\
\text { pedagogical work in } \\
\text { Biology in high } \\
\text { school, considering } \\
\text { the responsibility of } \\
\text { the school in the } \\
\text { process of } \\
\text { socialization of } \\
\text { knowledge, as well } \\
\text { as the importance of } \\
\text { education for human }\end{array}$ \\
\hline
\end{tabular}


4 Farias, D.B.; Lima, A.F.P.S.; Silva, E.T.B.; Silva, E.B.; Lima, J.B.A.S.; Silva, M.T.B.; Silva, W.C.; Silva, V.D.B.; Silva, G.E.R.; Souza. J.M.; Albuquerque, V.H.; Aguiar, A.C.; Silva, R.M.S.; Lima, C.G.O.; Bruce, J.C.S.; Costa L.L.L.; Silva, E.V.; Barbosa, V.C.; Gomes, V.S.; Alvares, E.B.S.O.; Morais, R.C.S. Information and communication technologies in biology teaching from the perspective of covid-19 in the light of studies already carried out...

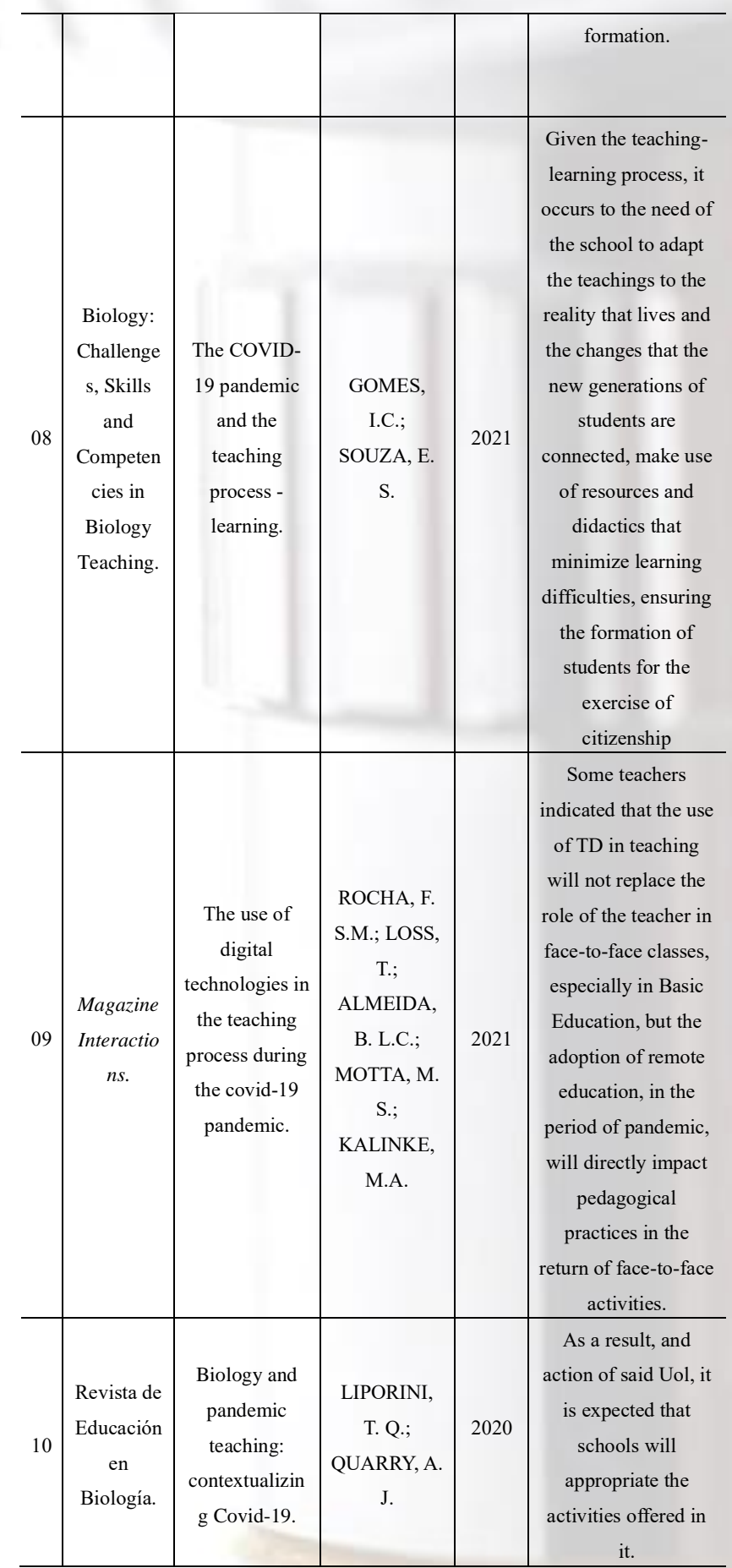

Source: Prepared by the researcher with data collected.

Given the educational context caused by the pandemic, knowing the experiences of biology teachers will contribute to the discussion of the theme in question, thus showing the difficulties and overcoming experienced by the educator, due to remote teaching. Among the various adaptations, conventional education was replaced by new digital platforms. Thus, requiring skills and skills that until then was not worked with graduates. In addition, the method of evaluating the student has become more complex, leaving in evidence that the practice of evaluation by single means, such as the test, is an outdated method (SANTOS, 2021; FREITAS, 2021).

On teaching and evaluation methodologies, Soares et al. (2021), elucidates that the most used tools were Google Meet (online class), Zoom (recording of classes and "slides") Google classroom (activities made by students), the latter was the main way to check if students are experiencing and performing the exercises, because they send activities answered, the teacher gave a return through corrections and explanations of the proposed questions.

Thus, evaluating the student goes far beyond a simple and mere test, this post, Neto et al. (2021), argues that teacher training is needed from these new Digital Information and Communication Technologies, so that the skills needed for the teaching and learning process are successfully developed. Among many challenges in the educational context in the pandemic period, the use of digital technologies is one of the major factors pointed out, since a large majority did not have continued training and ended up being limited to conventional education. However, the lack of preparation of teachers regarding the use of digital technologies can generate a deficit in communication and learning of students. However, it is necessary that institutions need to be encouraged to continue teacher training (ROCHA et al., 2021; MIRANDA et al., 2020).

Most teachers saw the use of ITDCs as a challenge, while others were an opportunity to reinvent themselves, as well as to improve their teaching methods. Thus, the relevance of biological knowledge is perceived, where it was essential in coping with the pandemic, that is, biology teachers had an even greater role in this period, being challenging, especially in the transfer of coherent information to students (CANI et al., 2020; GOMES, GOHETS SOUZA, 2021).

The teacher-student relationship is indispensable in advancing meaningful learning, and it is evident that the Brazilian educational system needs to be rebuilt, where the teacher needs to get out of the comfort zone, and go in search of professional training, always keeping on top of ICTs and innovations (LIPORINI \& PEDREIRA, 2020; Lima, LIMA; PEIXOTO; ECHALAR, 2020).

\section{Conclusions}

Given the relevance of the subject, it is remarkable that the faculty was essential in the period of the pandemic of covid-19, in the instruction of students in the face of a new educational paradigm. With this, the closure of schools and educational institutions due to the pandemic situation caused by covid-19, implied a new look and reflection of traditional education.

Thus, the need to monitor the available technological resources demonstrated that Emergency Remote Education (ERE), a model mediated by devices, ICT and internet, challenging teachers, students and even the educational institution itself, to an education ensured by digital means. 
At the end of the present study, it is suggested that teachers and researchers in the area of science and technology teaching, a deepening of the researched subject, with perspectives on the negative and positive impacts of remote classes in the post-pandemic period and technological advances.

\section{References}

[1] ALVES, J. N.; FARIA, B. L.; LEMOS, P. G. A.; COSTA, C. M.; SILVA, C. S.; OLIVEIRA, R. M. S. R. Ciências na pandemia: uma proposta pedagógica que envolve interdisciplinaridade e contextualização. Revista Thema, v. 18, p. 184-203, 2020. Disponível em:

$<$ https://doi.org/10.15536/thema.V18.Especial.2020. 184-203.1850>. Acesso em: 02 de ago. de 2021.

[2] BENÍCIO, L. A. O.; VAZ, I. F.; PELICIONI, B. B. A importância do uso das TICS no processo de ensinoaprendizagem frente à Pandemia do novo Coronavírus (COVID-19) / The importance of the use of TICS in the teaching-learning process facing the new Coronavírus Pandemic (COVID-19). Brazilian Journal of Health Review, v. 4, n. 3, 2021. Disponível

em: $<$ https://www.brazilianjournals.com/index.php/BJH R/article/view/29582/23325>. Acesso em: 02 de ago. de 2021 .

[3] CANI, J. B.; SANDRINI, E. G. C.; SOARES, G. M.; SCALZER, K. Educação e covid-19: a arte de reinventar a escola mediando a aprendizagem "prioritariamente" pelas tdic. Revista Ifes Ciência, São Paulo- SP, 2020. Disponível em: $<$ https://doi.org/10.36524/ric.v6i1.713>. Acesso em: 28 de Set. de 2021.

[4] FREITAS, T. C. R. C. O quê, como e por quê ensinar em tempos de pandemia? Uma análise da percepção docente acerca do uso da rede social Instagram no Ensino remoto de uma turma de Ensino Médio. Ensino de Ciências e Biologia em Espaços não Escolares e Divulgação Científica, Minas Gerais-MG, 2021. Disponível em: $<0.46943$ /VIII.ENEBIO.2021.01.405 $>$. Acesso em: 28 de set. de 2021.

[5] GOMES, I. C.; SOUZA, E. S. A pandemia de COVID-19 e o processo de ensino - aprendizagem. Biologia: Desafios, Habilidades e Competências no Ensino de Biologia, São Paulo-SP, 2021.

[6] LIMA, W. R.; PEIXOTO, J.; ECHALAR, A. D. L. F. Ações educacionais em tempos de pandemia: reflexões sobre a biologia no ensino médio. Olhar de Professor, São Paulo-SP, 2020. Disponível em: $<$ https://www.semanticscholar.org/paper/A\%C3\%87
$\%$ C3\%95ES-EDUCACIONAIS-EM-TEMPOS-DEPANDEMIA\%3A-REFLEX\%C3\%95ES-LimaPeixoto/eb602f2ca9e719adbd8a38b39ab0668520b5 bd48>. Acesso em: 28 de set. de 2021.

[7] LIPORINI, T. Q.; PEDREIRA, A. J. Ensino de Biologia e pandemia: contextualizando a Covid-19. Revista de Educación en Biología, Brasília-DF, 2021. Disponível $<$ file:///C:/Users/darla/AppData/Local/Temp/73Texto\%20del\%20art\%C3\%ADculo-1282-1-1020200924-1.pdf $>$. Acesso em: 28 de set. de 2021.

[8] MACHADO, P. L. P. Educação em tempos de pandemia: o ensinar através de tecnologias e mídias digitais. Revista Científica Multidisciplinar Núcleo do Conhecimento, v. 8, n. 6, p. 58-68, 2020. Disponível em: $<$ https://www.nucleodoconhecimento.com.br/educac ao/tempos-de-pandemia $>$. Acesso em: 02 de ago. de 2021.

[9] MIRANDA, K. K. C. O.; LIMA, A. S.; OLIVEIRA, V. C. M.; TELLES, C. B.S. Aulas remotas em tempo de pandemia: desafios e percepções de professores e alunos. VII Congresso Nacional de EducaçãoCONEDU, Maceió-AL, 2020.

[10] MOREIRA, M. E, S.; CRUZ, I. L. S.; SALES, M. E. N.; MOREIRA, N. I. T.; FREIRE, H. C.; MARTINS, G. A.; AVELINO, G. H. F.; JÚNIOR, S. A.; POPOLIM, R. S. N. Metodologias e tecnologias para educação em tempos de pandemia COVID-19. Brazilian Journal of Health Review, v. 3, n. 3, 2020. Disponível em: $<$ https://www.brazilianjournals.com/index.php/BJH $\mathrm{R} /$ article/view/11584>. Acesso em: 02 de ago. de 2021.

[11]NETO, J. S.; PINHO, F. V. A.; MATOS, H. L.; LOPES, A. R. O.; CERQUEIRA, G. S.; SOUZA, E. P. Tecnologias de ensino utilizadas na Educação na pandemia COVID-19: uma revisão integrativa. Research, Society and Development, São Paulo-SP, 2021. Disponível em: $<$ https://rsdjournal.org/index.php/rsd/article/view/11 974>. Acesso em: 28 de set. de 2021.

[12] PRETTO, N. L.; BONILLA, M. H. S.; SENA, I. P. F. S. (Org.). Educação em tempos de pandemia: reflexões sobre as implicações do isolamento físico imposto pela COVID-19. Edição do autor, SalvadorBA, 2020. Disponível em: $<$ https://avaliacaoeducacional.com/2020/05/26/gecufba-educacao-em-tempos-de-pandemia/ $>$. Acesso em: 26 de ago. de 2021.

[13] ROCHA, F. S. M.; LOSS, T.; ALMEIDA, B. L. C.; MOTTA, M. S.; KALINKE, M. A. O uso de 
6 Farias, D.B.; Lima, A.F.P.S.; Silva, E.T.B.; Silva, E.B.; Lima, J.B.A.S.; Silva, M.T.B.; Silva, W.C.; Silva, V.D.B.; Silva, G.E.R.; Souza. J.M.; Albuquerque, V.H.; Aguiar, A.C.; Silva, R.M.S.; Lima, C.G.O.; Bruce, J.C.S.; Costa L.L.L.; Silva, E.V.; Barbosa, V.C.; Gomes, V.S.; Álvares, E.B.S.O.; Morais, R.C.S. Information and communication technologies in biology teaching from the perspective of covid-19 in the light of studies already carried out...

tecnologias digitais no processo de ensino durante a pandemia da covid-19. Revista Interações, ParanáPR, 2021. Disponível em: $<$ https://doi.org/10.25755/int.20703>. Acesso em: 28 de set. de 2021.

[14] SANTOS, D. S. Tecnologias de Informação e Comunicação (TICs): uma abordagem no ensino remoto de Química e Nanotecnologia nas escolas em tempos de distanciamento social. Revista LatinoAmericana de Estudos Cientifico, Brasília-DF, 2021. Disponível

em: $<$ http://dx.doi.org/10.46375/relaec.33855>. Acesso em: 28 de set. de 2021.

[15] SILVA, R. S. Uso de TIC'S no ensino remoto emergencial: um estudo de caso da EMEF Severino Ramos Da Nóbrega. VII Congresso Nacional de Educação-CONEDU, Maceió-AL, 2020. Disponível em:

$<$ https://editorarealize.com.br/editora/anais/conedu/ 2020/TRABALHO_EV140_MD1_SA19_ID6434_0 1102020183334.pdf $>$. Acesso em: 02 de Ago. de 2021.

[16] SOARES, M. D.; SANTOS, A. N. B.; FARIAS, F. R.; LIMA, F. G. C. L. Ensino de biologia em tempos de pandemia: criatividade, eficiência, aspectos emocionais e significados. Revista Ibero- Americana de Humanidades, Ciências e Educação- REASE, Acaraú-CE, 2021. Disponível em: $<$ https://periodicorease.pro.br/rease/article/view/630 >. Acesso em: 28 de set. de 2021. 